\title{
Phytotoxic and antioxidant activity of seven native fruits of Brazil
}

\author{
Marize Terezinha Lopes Pereira Peres ${ }^{1}$, José Rodrigo Regis Lopes ${ }^{1}$, \\ Cristiane Bezerra da Silva ${ }^{1}$, Ana Carina Silva Cândido' ${ }^{1}$, Euclésio Simionatto ${ }^{2,4}$, \\ Márcia Regina Pereira $\mathrm{Cabral}^{2}$, Rita Machado Oliveira², Janaina Thomasi Facco², \\ Cláudia Andréa Lima Cardoso ${ }^{3}$ and Pedro Henrique Simas ${ }^{2}$
}

Received: 13 December, 2012. Accepted: 29 October, 2013

\begin{abstract}
We investigated antioxidant capacity, phenolic content and phytotoxic effects in seven species of fruit native to Brazil: Acrocomia aculeata, Hymenaea stigonocarpa, Tamarindus indica, Byrsonima intermedia, Psidium firmum, Myrciaria cauliflora and Ficus obtusifolia. Phytotoxic effects were assessed from crude ethanol extracts and semipurified fractions. In four of the seven fruits, total phenolic content, as determined by Folin-Ciocalteu assay, was higher in the peel than in the pulp. We found that total phenolic content correlated significantly with antioxidant capacity. High-performance liquid chromatography with diode array detection revealed the presence of the flavonoids quercetin and rutin in some fruits. We also evaluated the allelopathic effects of the crude ethanol extract and semipurified fractions. In most of the essays, the ethyl acetate fractions showed the highest level of activity.
\end{abstract}

Key words: Brazil; fruit; phytotoxic effects; antioxidant capacity; total phenolic content

\section{Introduction}

The continued use of herbicides, especially in areas of monoculture, has led to the emergence of herbicide-resistant weed biotypes, which has caused a significant increase in production costs and serious problems of environmental contamination (Macias et al. 2000). Recent agricultural studies have focused on the use of allelochemicals as herbicides, with the objective of developing practices that are more sustainable (Chon et al. 2003). Allelopathic interactions are mediated by secondary metabolites released into the environment by donor plants, and those metabolites can affect the growth and development of the surrounding plants, in natural ecosystems as well as in agricultural systems (Inderjit \& Duke 2003). Therefore, the production and application of extracts obtained from species that have allelopathic effects is viewed as an alternative to the use of synthetic agrochemicals as a means of achieving sustainable management.

Various biologically active compounds that are now widely used in Brazil were developed from vegetable, animal or microbial products (Barbosa et al. 2002). Researchers have discovered many chemical compounds derived from plants that inhibit the growth of vegetation. One example is artemisinin, a sesquiterpenoid produced by Artemisia annua L., that is highly phytotoxic (Duke \& Abbas 1996).
Another example is sorgoleone, an allelopathic compound isolated from Sorghum species and found to have potent phytotoxic properties in studies of plant-plant interactions (Duke et al. 2001). Vokou et al. (2003) investigated the allelopathic potential of 47 terpenoids from various groups, evaluating the effects of those compounds on the germination and growth of Lactuca sativa. The authors found that, although 24 of those 47 compounds were extremely active (> 85\%), only five inhibited the germination of $L$. sativa seeds.

In recent decades, studies aimed at elucidating the antioxidant properties of plant-derived products have made major advances, reflecting the growth in the number of scientific studies dealing with this issue. All of the major taxonomic groups assessed (algae, bryophytes, pteridophytes, gymnosperms and angiosperms) have yielded substances with antioxidant properties.

It is known that certain fruits present antioxidant activity and that the concentrations of antioxidant compounds are higher in the skin, peel and seeds than in the pulp, or even that the phytochemical profile is different in those parts of the fruit (Guo et al. 2003). Some authors have stated that vitamin $\mathrm{C}$ is the major contributor to antioxidant activity in fruit. However, many others have found that the majority of the antioxidant activity in fruit is attributable to

\footnotetext{
${ }^{1}$ Universidade Federal de Mato Grosso do Sul, Faculdade de Engenharias, Arquitetura e Urbanismo e Geografia, Campo Grande, MS, Brazil

${ }^{2}$ Universidade Estadual de Mato Grosso do Sul, Programa de Pós-graduação em Recursos Naturais, Naviraí, MS, Brazil

${ }^{3}$ Universidade Estadual de Mato Grosso do Sul, Programa de Pós-graduação em Recursos Naturais, Dourados, MS, Brazil

${ }^{4}$ Author for correspondence: eusimionatto@yahoo.com.br
} 
phenolic compounds (Heim et al. 2002). In a study of $11 \mathrm{di}-$ fferent fruits, Sun et al. (2002a) demonstrated that vitamin C made a minimal contribution and that phenolic compounds accounted for the majority of the antioxidant activity. The pulp of fruits that do not contain phenolic compounds, such as pineapple, soursop, cupuassu and passion fruit, present lower levels of antioxidant activity.

Various studies of antioxidant activity in fruit have involved the quantification of phenolic compounds in extracts obtained from the fruits under study (Netzel et al. 2007; Alothman et al. 2009; Hervert-Hernández et al. 2011; Lim et al. 2007; Mattila et al. 2006; Bennett et al. 2010; Koli et al. 2010). In parallel with those studies are analyses of the concentration of phenolic compounds in beverages prepared from such fruits from different regions of the planet. Netzel et al. (2007) investigated 20 species of forest fruits native to Australia, in terms of their antioxidant capacity, as well as the variety and concentrations of their phenolic compounds. Among those 20 species, the fruit extracts of five presented high antioxidant activity, comparable to the standard (blueberry extract), whereas those of another six species presented phenolic compounds at concentrations that were up to 3.9 times higher than the standard. At the end of the study, the authors concluded that the fruit extracts of 12 species were rich sources of antioxidants and recommended that those extracts be studied in greater detail, with the objective of developing industrial applications for those substances as functional foods.

With a view to increasing appreciation of the native vegetation of Brazil, our objective in the present study was to evaluate the allelopathic and antioxidant properties of the native fruit species Acrocomia aculeata (Jacq.) Lodd. Ex Mart. (Arecaceae), Hymenaea stigonocarpa Mart. Ex Hayne (Fabaceae), Tamarindus indica L. (Fabaceae), Byrsonima intermedia A. Juss. (Malpighiaceae), Psidium firmum O. Berg (Myrtaceae), Myrciaria cauliflora (Mart.) O. Berg (Myrtaceae) and Ficus obtusifolia Kunth (Moraceae).

\section{Material and methods}

\section{Botanical material}

We collected fruit specimens over the course of 2008, the timing of the collection depending on the fruiting period and maturation status of each species, which was determined by the visual appearance, as described in the literature (Proença et al. 2000; da Silva et al. 2001; Pott \& Pott 1994). All specimens were collected in areas of cerrado (savanna) within the municipality of Campo Grande, in the state of Mato Grosso do Sul, Brazil. A voucher specimen of each species is on deposit at the Herbarium of the Federal University of Mato Grosso do Sul, in Campo Grande (code, CGMS). We collected fruit specimens of the species Acrocomia aculeata, Hymenaea stigonocarpa, Tamarindus indica, Byrsonima intermedia, Psidium firmum, Myrciaria cauliflora and Ficus obtusifolia.

\section{Obtaining the crude ethanol extracts and semipurified fractions}

Fresh specimens were ground separately, each part of the fruit (peel and pulp) or whole fruits being submitted to maceration with commercial-grade ethanol $(\mathrm{m} / \mathrm{v}, 1: 2)$, at room temperature and in total darkness. After seven days, the solutions were filtered and the solvent was evaporated at $\pm 40^{\circ} \mathrm{C}$ under vacuum in a rotary evaporator, in order to obtain the crude ethanol extracts (CEEs) from the peel, pulp and whole fruits. The CEEs were fractioned by liquid-liquid partitioning with solvents of increasing polarity, hexane and ethyl acetate, resulting in the following semipurified fractions: the hexane fraction (HF); the ethyl acetate fraction (EAF); and the ethanol-water fraction (EWF).

\section{Determination of the total phenolic content}

The total phenolic content of the samples was determined by spectrophotometry in the visible range with the Folin-Ciocalteu method (Meda et al. 2005; Lin \& Tang 2007). The CEEs and semipurified fractions ( $5 \mathrm{mg}$ of each) were dissolved in $5 \mathrm{ml}$ of water. Aliquots $(100 \mu \mathrm{l}$ of each solution) were transferred to 5 - $\mathrm{ml}$ flasks, to which $1 \mathrm{ml}$ of distilled water was added, after which we added $0.2 \mathrm{ml}$ of Folin-Ciocalteu reagent. Finally, we added $0.6 \mathrm{ml}$ of a solution of $20 \% \mathrm{Na}_{2} \mathrm{CO}_{3}$ and diluted to volume with water. After $90 \mathrm{~min}$, the absorbance of the samples was measured at $760 \mathrm{~nm}$. The total phenolic content was determined by interpolation of the absorbance of the samples against a calibration curve constructed with gallic acid standards $(25-600 \mu \mathrm{g} / \mathrm{ml})$, expressed as milligrams of gallic acid equivalents (GAEs) per milligram of extract. All analyses were performed in triplicate.

\section{Analysis of antioxidant activity}

To detect antioxidant activity, we added $50 \mu$ solutions of various concentrations of the extracts and semipurified fractions, in methanol $\left(0.625,1.25,2.5,5.0\right.$ and $\left.10.0 \mathrm{mg} . \mathrm{ml}^{-1}\right)$, to $5 \mathrm{ml}$ of a methanolic solution of diphenyl picryl hydrazine (DPPH) at $0.004 \%$. After 30 min of reaction at room temperature, the absorbance of the samples was measured against a blank at $517 \mathrm{~nm}$ (Katalinic et al. 2004; Sharma \& Bhat 2009). The inhibition of the DPPH free radical (in \%) was calculated by the following expression:

$$
I \%=\left(A_{\text {blank }}-A_{\text {sample }} / A_{\text {blank }}\right) \times 100
$$

where $I \%$ is the inhibition (in \%), $A_{\text {blank }}$ is the absorbance of the blank, and $A_{\text {sample }}$ is the absorbance of the sample. All analyses were performed in triplicate.

\section{Bioassays of allelopathic activity}

We evaluated the allelopathic effects of the CEEs and semipurified fractions on the germination and growth of 
Marize Terezinha Lopes Pereira Peres, José Rodrigo Regis Lopes, Cristiane Bezerra da Silva, Ana Carina Silva Cândido, Euclésio Simionatto, Márcia Regina Pereira Cabral, Rita Machado Oliveira, Janaina Thomasi Facco, Cláudia Andréa Lima Cardoso and Pedro Henrique Simas

lettuce (Lactuca sativa L. cv. Grand Rapids) and onions (Allium cepa L. cv. Baia Periforme). For the bioassays, we prepared a stock solution at a concentration of 1000 $\mathrm{mg} . \mathrm{L}^{-1}$ based on the mass calculated for each CEE and semipurified fraction, taking the relative humidity into account, and the fractions were prepared for dilution by dissolution in $0.1 \%$ dimethyl sulfoxide (Dayan et al. 2000) at concentrations of $500 \mathrm{mg} . \mathrm{L}^{-1}$ and $250 \mathrm{mg} . \mathrm{L}^{-1}$. The solutions were buffered with a solution of $10 \mathrm{mM} 2-(\mathrm{N}-$ -morpholino)ethanesulfonic acid, and the $\mathrm{pH}$ was adjusted to 6.0 with a solution of $0.1 \mathrm{~N}$ potassium hydroxide. As a control, we performed a similar procedure without the CEEs or semipurified fractions (Macias et al. 2000).

For the germination bioassays, $5.0 \mathrm{ml}$ of each solution (Macias et al. 2000), at concentrations of 250, 500 and $1000 \mathrm{mg} . \mathrm{L}^{-1}$, were poured onto autoclaved Whatman no. 1 filter paper on Petri plates $(9.0 \mathrm{~cm}$ in diameter). Onto each filter paper, we randomly distributed 50 diaspores of the target species (lettuce and onion). This procedure was performed in quadruplicate for each solution (Brasil 2009). The Petri plates were placed into a biological oxygen demand incubator (growth chamber), under a $160 \mathrm{~W}$ light, at a constant relative humidity $( \pm 80 \%)$ and temperature (adjusted to each target species). We evaluated germination by counting seedlings on a daily basis (every $12 \mathrm{~h}$ for lettuce seedlings) in accordance with the Rules for Seed Analysis established by the Brazilian Ministry of Agriculture and Agrarian Reform (Brasil 2009). Normal seedlings were defined as those that showed all of the essential structures of a developed embryo, with a radicle of at least $2.0 \mathrm{~mm}$ in length. The experiment was considered concluded when there was no new germination for three consecutive days.

For the growth bioassays, the seeds were pre-germinated on filter paper wetted with $5.0 \mathrm{ml}$ of distilled water in Petri plates. After germination, we selected 80 seedlings (four groups of 20), per treatment. We applied each treatment in quadruplicate ( 20 seedlings at a time). In brief, we transferred seedlings were to Petri plates containing the treatment solutions, using a procedure similar to that described for the germination bioassays (Macias et al. 2000). At three days after radicle emergence, we measured the length of the root and of the hypocotyl/ coleoptile (in ten seedlings per plate), using millimeter paper. To determine the dry mass, we dried the seedlings to a constant weight in a drying oven at $60^{\circ} \mathrm{C}$.

For each CEE and semipurified fraction evaluated, the experimental design was completely randomized, with four treatments $\left(0,250,500\right.$ and $\left.1000 \mathrm{mg} \cdot \mathrm{L}^{-1}\right)$ performed in quadruplicate. The experimental sample comprised 50 diaspores for germination assay and ten for the quantification of growth and dry mass. The data were submitted to ANOVA. When the F-test indicated a difference, the means were compared with Dunnett's test, at a 5\% level of statistical significance.

\section{Instrumentation and chromatography}

a) Preparation of the extracts

We weighed the extracts on an analytical scale, after which they were dissolved in methanol and transferred to volumetric flasks (at concentrations between $2000 \mu \mathrm{g} \cdot \mathrm{ml}^{-1}$ and 3000 $\left.\mu \mathrm{g} \cdot \mathrm{ml}^{-1}\right)$. They were then analyzed by high-performance liquid chromatography with diode array detection (HPLC-DAD).

b) HPLC-DAD and chromatographic conditions

We employed a liquid chromatograph (210; Varian Instruments, Palo Alto, CA, USA) with diode array detection (sweep range, 200-800 $\mathrm{nm}$ ) and the software Workstation Star (Varian Instruments). We used a C-18 reverse-phase column $(25 \mathrm{~cm} \times 4.6 \mathrm{~mm} \times 5 \mu \mathrm{m})$ and a reverse-phase pre-column $(2,5 \mathrm{~cm} \times 3 \mathrm{~mm})$. The samples were eluted in a graded system: from $16 \%$ methanol/ $84 \%$ water to $41 \%$ methanol $/ 59 \%$ water in $15 \mathrm{~min}$, to $21 \%$ methanol $/ 79 \%$ water in $20 \mathrm{~min}$ and to $100 \%$ of methanol in $30 \mathrm{~min}$. At $40 \mathrm{~min}$, we began a gradual return to the initial condition, which was achieved at $50 \mathrm{~min}$. The total analysis time was $50 \mathrm{~min}$. The flow rate was $1 \mathrm{ml} / \mathrm{min}$, and the injection volume was $20 \mu \mathrm{l}$.

\section{Validation parameters}

We evaluated the following parameters: specificity, linearity, interval, precision (repeatability and intermediate precision) and exactness.

Specificity - The method was considered specific if there were no simultaneous peaks in the retention times for rutin and quercetin. In addition, we evaluated the purity of the chromatographic peaks on the basis of the absorption spectra generated by the diode array detection.

\section{a) Linearity and interval}

The concentrations of rutin and quercetin were determined with a graded system. The injections were performed in triplicate, and the results are expressed as the mean of the determinations, in milligrams of rutin or quercetin per gram of extract $(\mathrm{m} / \mathrm{m})$. We weighed out $2 \mathrm{mg}$ of the rutin and quercetin reference standards, which were then dissolved in methanol. The resulting solutions were transferred to 25 $\mathrm{ml}$ flasks and diluted to volume with methanol (thus creating the mother solutions). Aliquots of the mother solution were diluted with methanol in order to obtain solutions of rutin and quercetin at 4.0,8.0,12.0,16.0 and $20.0 \mu \mathrm{g} / \mathrm{ml}$. We injected $20 \mu \mathrm{l}$ of each dilution into the chromatograph. The standard curves were analyzed by linear regression related to the area of the peak versus the concentrations of rutin and quercetin. The regression line for rutin was $\mathrm{y}=8.59083 \mathrm{x}+214.562(\mathrm{R}=0.9998)$, compared with $\mathrm{y}=$ $45.20125 \mathrm{x}+200.91181(\mathrm{R}=0.9997)$ for quercetin.

\section{b) Precision}

The precision of the method was evaluated through analyses at three concentrations for each analyte, performed 
in triplicate and on three different days. Working standards, in methanol, were added to the extracts. The values obtained for each concentration were submitted to ANOVA to estimate the intra- and inter-assay precision, both expressed as the coefficient of variation (in \%). In the evaluation of the precision and exactness, the coefficients of variation were below $5 \%$ for the inter- and intra-day assays. These data indicate that the method was reproducible on the three different days.

Limits of detection and quantification - For rutin and quercetin alike, the detection limits were based on a signal-to-noise ratio of 3 , whereas the quantification limits were based on a signal-to-noise ratio of 10 . The detection limits obtained were $0.03 \mu \mathrm{g} / \mathrm{ml}$ and $0.10 \mu \mathrm{g} / \mathrm{ml}$ for rutin and quercetin, respectively, compared with $0.08 \mu \mathrm{g} / \mathrm{ml}$ and 0.26 $\mu \mathrm{g} / \mathrm{ml}$, respectively, for the limits of quantification.

\section{Results and discussion}

\section{Total phenolic content and antioxidant activity}

On the basis of our results, it was possible to distinguish among and group the extracts and semipurified fractions according to their characteristics (yield, antioxidant activity, allelopathic effects and total phenolic content). In some of the species evaluated, there were significant differences, in terms of those characteristics, between the pulp and peel of the fruit.

The preliminary qualitative evaluation of the CEEs and semipurified fractions, by thin-layer chromatography in silica gel, revealed with a methanol solution containing 0.2 $\mathrm{mmol} / \mathrm{L}$ of the DPPH free radical, indicated the presence of substances with antioxidant activity, as evidenced by yellow spots on a purple background on the chromatography plates, resulting from the reduction of the DPPH free radical. Most of the samples exhibited activity, with the following exceptions: the HF of the pulp of Myrciaria cauliflora; the EWF of the peel of Tamarindus indica; the CEE and semipurified fractions of the pulp of Tamarindus indica; the HF of the peel of Hymenaea stigonocarpa; the CEE, EAF and EWF of the pulp of Hymenaea stigonocarpa; the EWFs of the pulp and peel of Acrocomia aculeata; the HF of Psidium firmum; and the HF and EWF of Ficus obtusifolia. Of the 44 samples tested, 30 were positive and 14 were negative on the thin-layer chromatography DPPH test.

We conducted the quantitative evaluation by spectrophotometry. By reading the absorbances of the various concentrations, we determined the $50 \%$ inhibitory concentration $\left(\mathrm{IC}_{50}\right)$, defined as the quantity of sample needed in order to reduce the initial concentration of DPPH by $50 \%$. When possible, we prepared the CEE and the semipurified fractions of the pulp and peels of each species of fruit. The most significant results were obtained for the EAF of the peel of Myrciaria cauliflora $\left(\mathrm{IC}_{50}=1.33 \pm 0.08 \mu \mathrm{g} / \mathrm{mg}\right.$ ); the EAF of Byrsonima intermedia $\left(\mathrm{IC}_{50}=1.38 \pm 0.11 \mu \mathrm{g} / \mathrm{mg}\right.$ ); the CEE and EAF of Tamarindus indica $\left(\mathrm{IC}_{50}=2.57 \pm 0.18\right.$ $\mu \mathrm{g} / \mathrm{mg}$ and $3.72 \pm 0.27 \mu \mathrm{g} / \mathrm{mg}$, respectively); and the EAF of Psidium firmum $\left(\mathrm{IC}_{50}=3.82 \pm 0.07 \mu \mathrm{g} / \mathrm{mg}\right.$ ). In the species of fruits from which we obtained the CEEs and semipurified fractions separately, we found the highest levels of antioxidant activity in the peels of the fruit, especially in Tamarindus indica and Myrciaria cauliflora. For all of the fruit species evaluated, the greatest antioxidant potentials were observed in the CEEs and EAFs of the samples. Among the 22 CEEs and EAFs (11 of each), the most active included six EAFs (from the whole fruit of Byrsonima intermedia; the peel of Myrciaria cauliflora; the peel of Acrocomia aculeata; and the pulp of Acrocomia aculeata, Psidium firmum and Ficus obtusifolia) and three CEEs (from the pulp of Myrciaria cauliflora; the peel of Tamarindus indica; and the peel of Hymenaea stigonocarpa), whereas two CEEs (from the pulp of Tamarindus indica and Hymenaea stigonocarpa) were inactive. The total concentrations are shown in Tab. 1.

Because of the high antioxidant activity of some extracts and the possibility that the fruit contained phenolic compounds, we determined the total phenolic content of the samples using the Folin-Ciocalteu method. We determined the phenolic contents (in GAEs) using an analytic curve, constructed by reading the absorbance of solutions with different concentrations of gallic acid (10-600 $\mu \mathrm{g} / \mathrm{ml})$. As can be seen in Tab. 1, the highest total phenolic contents (in $\mu \mathrm{g} \mathrm{GAE} / \mathrm{mg}$ of extract) were found in the EAF of the peel of Acrocomia aculeata ( $304.32 \pm 30.57 \mathrm{GAE} / \mathrm{mg}$ of extract); the EWF of the pulp of Myrciaria cauliflora $(183.50 \pm 20.40$ $\mu \mathrm{g} \mathrm{GAE} / \mathrm{mg}$ of extract); the EAF of the peel of Myrciaria cauliflora ( $222.32 \pm 19.28 \mu \mathrm{g} \mathrm{GAE} / \mathrm{mg}$ of extract); the EAF of Psidium firmum (138.32 $\pm 11.60 \mu \mathrm{g} \mathrm{GAE} / \mathrm{mg}$ of extract); the CEE of Byrsonima intermedia (119.12 $\pm 9.28 \mu \mathrm{g} \mathrm{GAE} /$ $\mathrm{mg}$ of extract); the EAF of Byrsonima intermedia (181.12 $\pm 14.84 \mu \mathrm{g} \mathrm{GAE} / \mathrm{mg}$ of extract); and the CEE of the peel of Tamarindus indica (183.28 $\pm 17.37 \mu \mathrm{g} \mathrm{GAE} / \mathrm{mg}$ of extract).

In samples that presented low values of $\mathrm{IC}_{50}$ on the $\mathrm{DPPH}$ test (high antioxidant activity), we quantified the concentrations of the flavonoids rutin and quercetin through HPLC (Tab. 2). Among the extracts evaluated, the highest concentrations of rutin and quercetin were observed for the EAF obtained from the peel of Tamarindus indica (5.68 $\mathrm{mg} / \mathrm{g}$ and $6.27 \mathrm{mg} / \mathrm{g}$, respectively) and the EAF obtained from Psidium firmum $(4.39 \mathrm{mg} / \mathrm{g}$ and $7.87 \mathrm{mg} / \mathrm{g}$, respectively). There were five extracts that contained both rutin and quercetin, and there were two extracts that contained rutin only (the CEEs obtained from Psidium firmum and from the peel of Hymenaea stigonocarpa). In the samples showing significant antioxidant activity and not containing rutin and quercetin, that activity was attributed to the presence of other phenolic compounds, given that the low values of $\mathrm{IC}_{50}$ were concordant with the high phenolic content. We obtained similar results (high antioxidant activity and phenolic content, without rutin or quercetin) for the CEE and EAF of Byrsonima intermedia, as well as for the EAF of the peel of Acrocomia aculeata. 
Marize Terezinha Lopes Pereira Peres, José Rodrigo Regis Lopes, Cristiane Bezerra da Silva, Ana Carina Silva Cândido, Euclésio Simionatto, Márcia Regina Pereira Cabral, Rita Machado Oliveira, Janaina Thomasi Facco, Cláudia Andréa Lima Cardoso and Pedro Henrique Simas

Table 1. Yield, total phenolic content and 50\% inhibitory concentration for the crude extracts and semipurified fractions of fruits native to Brazil, including Byrsonima intermedia A. Juss., Myrciaria cauliflora (Mart.) O. Berg., Tamarindus indica L., Hymenaea stigonocarpa Mart. Ex Hayne, Acrocomia aculeata (Jacq.) Lodd. Ex Mart., Psidium firmum O. Berg. and Ficus obtusifolia Kunth.

\begin{tabular}{|c|c|c|c|}
\hline \multirow[t]{2}{*}{ Sample/substance } & \multirow{2}{*}{$\begin{array}{l}\text { Yield } \\
(\%)\end{array}$} & \multirow{2}{*}{$\begin{array}{c}\text { Total phenolic content }{ }^{*} \\
\text { ( } \mu \text { g GAE/mg of extract) } \\
\text { Mean } \pm \text { SEM }\end{array}$} & \multirow{2}{*}{$\begin{array}{c}\mathrm{IC}_{50}^{*} \\
(\mu \mathrm{g} / \mathrm{mg}) \\
\text { Mean } \pm \mathrm{SEM}\end{array}$} \\
\hline & & & \\
\hline \multicolumn{4}{|c|}{ Byrsonima intermedia (whole fruit) } \\
\hline Crude ethanol extract & 25.1 & $119.12 \pm 9.28$ & $1.76 \pm 0.18$ \\
\hline Ethyl acetate fraction & 13.9 & $181.12 \pm 14.84$ & $1.38 \pm 0.11$ \\
\hline Hexane fraction & 2.28 & nd & $3.97 \pm 0.36$ \\
\hline Ethanol-water fraction & 30.4 & $50.32 \pm 2.56$ & $4.32 \pm 0.45$ \\
\hline \multicolumn{4}{|l|}{ Myrciaria cauliflora (peel) } \\
\hline Crude ethanol extract & 26.8 & $45.92 \pm 2.47$ & $4.65 \pm 0.71$ \\
\hline Ethyl acetate fraction & 16.3 & $222.32 \pm 19.28$ & $1.33 \pm 0.08$ \\
\hline Hexane fraction & 1.3 & nd & $4.95 \pm 0.40$ \\
\hline Ethanol-water fraction & 56.5 & $6.72 \pm 1.97$ & $7.90 \pm 1.11$ \\
\hline \multicolumn{4}{|l|}{ Myrciaria cauliflora (pulp) } \\
\hline Crude ethanol extract & 8.7 & $8.72 \pm 0.84$ & $8.84 \pm 1.23$ \\
\hline Ethyl acetate fraction & 3.1 & $7.92 \pm 0.56$ & $9.13 \pm 1.47$ \\
\hline Hexane fraction & 0.01 & nd & nd \\
\hline Ethanol-water fraction & 2.2 & $183.5 \pm 20.40$ & $2.37 \pm 0.21$ \\
\hline \multicolumn{4}{|l|}{ Tamarindus indica (peel) } \\
\hline Crude ethanol extract & 39.4 & $183.28 \pm 17.37$ & $2.57 \pm 0.18$ \\
\hline Ethyl acetate fraction & 27.1 & $57.95 \pm 5.20$ & $3.72 \pm 0.27$ \\
\hline Hexane fraction & 4.2 & nd & $15.32 \pm 2.48$ \\
\hline Ethanol-water fraction & 26 & nd & nd \\
\hline \multicolumn{4}{|l|}{ Tamarindus indica (pulp) } \\
\hline Crude ethanol extract & 11.2 & nd & nd \\
\hline Ethyl acetate fraction & 7.7 & nd & nd \\
\hline Hexane fraction & 1.4 & nd & nd \\
\hline Ethanol-water fraction & 76.1 & nd & nd \\
\hline \multicolumn{4}{|l|}{ Hymenaea stigonocarpa (peel) } \\
\hline Crude ethanol extract & 35.3 & nd & $26.11 \pm 4.76$ \\
\hline Ethyl acetate fraction & 27.8 & nd & $30.83 \pm 5.82$ \\
\hline Hexane fraction & 44.7 & nd & nd \\
\hline Ethanol-water fraction & 22.1 & $59.92 \pm 6.45$ & $9.57 \pm 0.92$ \\
\hline \multicolumn{4}{|l|}{ Hymenaea stigonocarpa (pulp) } \\
\hline Crude ethanol extract & 9.4 & nd & nd \\
\hline Ethyl acetate fraction & 2.2 & $18 \pm 1.54$ & nd \\
\hline Hexane fraction & 4.1 & nd & $5.84 \pm 0.10$ \\
\hline Ethanol-water fraction & 9.5 & nd & nd \\
\hline \multicolumn{4}{|l|}{ Acrocomia aculeata (peel) } \\
\hline Crude ethanol extract & 32.1 & $70.8 \pm 7.28$ & $11.81 \pm 0.48$ \\
\hline Ethyl acetate fraction & 3.4 & $304.32 \pm 30.57$ & $1.86 \pm 0.13$ \\
\hline Hexane fraction & 2.3 & nd & $5.85 \pm 0.58$ \\
\hline Ethanol-water fraction & 32.7 & nd & nd \\
\hline
\end{tabular}


Table 1. Continuation.

\begin{tabular}{|c|c|c|c|}
\hline \multirow[t]{2}{*}{ Sample/substance } & Yield & $\begin{array}{l}\text { Total phenolic content } \\
\text { ( } \mu \mathrm{g} \text { GAE/mg of extract) }\end{array}$ & $\begin{array}{c}\mathrm{IC}_{50}^{*} \\
(\mu \mathrm{g} / \mathrm{mg})\end{array}$ \\
\hline & $(\%)$ & Mean \pm SEM & Mean \pm SEM \\
\hline \multicolumn{4}{|l|}{ Acrocomia aculeata (pulp) } \\
\hline Crude ethanol extract & 8.5 & $5.92 \pm 0.41$ & $17.03 \pm 2.64$ \\
\hline Ethyl acetate fraction & 2.9 & $79.12 \pm 4.50$ & $5.0 \pm 17.14$ \\
\hline Hexane fraction & 1.3 & nd & $19.10 \pm 3.41$ \\
\hline Ethanol-water fraction & 55.6 & nd & nd \\
\hline \multicolumn{4}{|l|}{ Psidium firmum (whole fruit) } \\
\hline Crude ethanol extract & 11.3 & $33.92 \pm 1.12$ & $14.96 \pm 0.97$ \\
\hline Ethyl acetate fraction & 35.1 & $138.32 \pm 11.60$ & $3.82 \pm 0.07$ \\
\hline Hexane fraction & 1.3 & nd & nd \\
\hline Ethanol-water fraction & 58.4 & $12.30 \pm 1.10$ & $20.3 \pm 3.48$ \\
\hline \multicolumn{4}{|l|}{ Ficus obtusifolia (whole fruit) } \\
\hline Crude ethanol extract & 6.3 & $3.12 \pm 0.21$ & $36.5 \pm 4.69$ \\
\hline Ethyl acetate fraction & 1.7 & $69.12 \pm 4.47$ & $10.3 \pm 0.83$ \\
\hline Hexane fraction & 1.5 & nd & nd \\
\hline Ethanol-water fraction & 53.2 & nd & nd \\
\hline Butylated hydroxyanisole & & & $1.70 \pm 0.20$ \\
\hline Rutin & & & $3.30 \pm 0.40$ \\
\hline Quercetin & & & $1.60 \pm 0.02$ \\
\hline
\end{tabular}

GAE - gallic acid equivalent(s); $\mathrm{IC}_{50}-50 \%$ inhibitory concentration (defined as the quantity of sample needed in order to reduce the initial concentration of diphenyl picryl hydrazine by $50 \%$ ); nd - no data (undetectable).

${ }^{\star}$ Assays performed in triplicate.

Table 2. Concentrations of rutin and quercetin in the samples showing significant antioxidant activity, including Acrocomia aculeata (Jacq.) Lodd. Ex Mart., Myrciaria cauliflora (Mart.) O. Berg., Tamarindus indica L., Psidium firmum O. Berg. and Hymenaea stigonocarpa Mart. Ex Hayne.

\begin{tabular}{lcc}
\hline Sample & $\begin{array}{c}\text { Quercetin } \\
\left(\mathrm{mg} \cdot \mathrm{g}^{-1}\right)\end{array}$ & $\begin{array}{c}\text { Rutin } \\
\left(\mathrm{mg} \cdot \mathrm{g}^{-1}\right)\end{array}$ \\
\hline Ethyl acetate fraction - pulp of Acrocomia aculeata & - & - \\
Crude ethanol extract - pulp of Acrocomia aculeata & - & - \\
Crude ethanol extract - peel of Acrocomia aculeata & - & - \\
Ethyl acetate fraction - peel of Acrocomia aculeata & $0.571 \pm 0.011$ & $1.710 \pm 0.024$ \\
Ethyl acetate fraction - peel of Myrciaria cauliflora & $0.302 \pm 0.012$ & $0.100 \pm 0.013$ \\
Crude ethanol extract - peel of Myrciaria cauliflora & $1.578 \pm 0.020$ & $2.989 \pm 0.019$ \\
Crude ethanol extract - peel of Tamarindus indica & $6.276 \pm 0.034$ & $5.686 \pm 0.021$ \\
Ethyl acetate fraction - peel of Tamarindus indica & $7.876 \pm 0.031$ & $4.393 \pm 0.021$ \\
Ethyl acetate fraction - whole fruit of Psidium firmum & - & - \\
Crude ethanol extract - whole fruit of Psidium firmum & - & - \\
Ethyl acetate fraction - whole fruit of Hymenaea stigonocarpa & - & $2.931 \pm 0.011$ \\
Crude ethanol extract - peel of Hymenaea stigonocarpa & & - \\
\hline
\end{tabular}

In the present study, we found that the extracts with the highest concentrations of phenolic compounds were, in general, also those that showed the highest levels of antioxidant activity. In most cases, the CEEs and the EAFs were the most active scavengers of the DPPH free radical. The fractioning of the CEE with ethyl acetate can increase the phenolic content, as we observed in the EAFs obtained from Byrsonima intermedia, from the peel of Myrciaria cauliflora and from the peel of Acrocomia aculeata, as well as from the pulp of Acrocomia aculeata, Psidium firmum and Ficus obtusifolia. These findings indicate that the antioxidant activity of some fruits can be potentiated by the fractioning of the CEE.

Some of the samples investigated presented considerable variation in the concentration of phenolic compounds, when the different parts of the fruit (pulp and peel). In Myrciaria cauliflora, Tamarindus indica and Acrocomia aculeata, species that are widely consumed by the local 
Marize Terezinha Lopes Pereira Peres, José Rodrigo Regis Lopes, Cristiane Bezerra da Silva, Ana Carina Silva Cândido, Euclésio Simionatto, Márcia Regina Pereira Cabral, Rita Machado Oliveira, Janaina Thomasi Facco, Cláudia Andréa Lima Cardoso and Pedro Henrique Simas

population, the highest total phenolic content is in the peel of the fruit. Therefore, we believe that there should be an active search for ways in which to utilize this part of the fruit. In most cases, the peels of these fruits are not consumed and are discarded as rubbish, which represents a great waste of phytonutrients, especially of those with antioxidant properties.

Fruits and their respective phenolic profiles are of considerable dietary importance. Fruits that have high phenolic contents and high antioxidant activity are typically sources of various bioactive compounds (Sun et al. 2002b; Sharma \& Bhat 2009). It has been demonstrated that phytochemicals have considerable influence on antioxidant activity, especially anthocyanins, which are phenolic pigments. The pulp of fruits that do not contain phenolic compounds, such as pineapple, soursop, cupuassu and passion fruit, present lower levels of antioxidant activity (Hervert-Hernández et al. 2011; Sharma \& Bhat 2009).

The daily consumption of polyphenols can be as high as one gram, which is much higher than that of any other phytochemical classified as an antioxidant (Manach et al. 2005). Plants synthesize hundreds of phenolic and polyphenolic compounds, which have a variety of structures and functions. The most widely studied of such compounds, in terms of their antioxidant properties, are the flavonoids, which have a common C6-C3-C6 skeleton consisting of two aromatic rings linked through a heterocyclic ring containing one oxygen atom. Among the approximately 4000 flavonoids described, the major classes are flavonols, catechins (or flavones), anthocyanidins and isoflavones. Within those classes, there are numerous structural variations, depending on the level of hydrogenation, hydroxylation, methylation and sulfonation of the molecules. In addition, flavonoids form complexes with sugars, lipids, amines and carboxylic acids (Duthie et al. 2000; Sun et al. 2002a).

\section{Bioassays of allelopathic effects}

The analysis of the allelopathic effects of the fruits evaluated indicated that the intensity varied in function of the extract, the semipurified fraction and the concentration employed. In the germination studies, we found that, for all of the CEEs and semipurified fractions evaluated, at least one concentration reduced the germination speed index and the germination percentage. The main results of the phytotoxicity studies showed that the EAFs obtained from the peel of the fruits produced greater inhibition than did the EAFs obtained from the pulp of the same fruits. The greatest inhibition of the germination percentage was achieved with the EAFs obtained from the peel of Acrocomia aculeata, Tamarindus indica, Byrsonima intermedia, Psidium firmum and Myrciaria cauliflora, all of which, at the concentration of $1000 \mathrm{mg} . \mathrm{L}^{-1}$, inhibited the germination of Allium cepa (onion) by more than $30 \%$ in comparison with the control.
In relation to the growth of the root, growth of the hypocotyl/coleoptile and accumulation of dry mass of the lettuce and onion seedlings, we found that at least one concentration of every CEE and semipurified fraction inhibited growth by more than $50 \%$ in at least one of the parameters studied (Fig. 1-3). Similar to the results of the germination tests, the results of the growth tests showed that greatest phytotoxic effects were exerted by the EAFs obtained from the peel or whole fruits (Byrsonima intermedia and Psidium firmum). The greatest inhibitory effects were observed for the EAFs obtained from the peels of Acrocomia aculeata (Fig. 1) and Tamarindus indica (Fig. 2), as well as for the EAFs obtained from the whole fruits of $B$. intermedia (Fig. 3) and P. firmum (Fig. 3). In onion seedlings, all of those EAFs (at a concentration of $1000 \mathrm{mg} \cdot \mathrm{L}^{-1}$ ) inhibited the growth of the root (by 69\%, on average), the growth of the coleoptile (by $77 \%$, on average) and the accumulation of dry mass (by $57 \%$, on average), the seedlings submitted to those treatments having a chlorotic appearance. Alterations in the pattern of germination and growth can have various effects at the primary level (Gusman et al. 2008). According to Ferreira \& Aquila (2000), such effects include the following, which can occur in isolation or in combination: altered membrane permeability; alterations in the transcription and translation of DNA; altered respiration (oxygen sequestration); and alterations in the conformation of enzymes and receptors. We found that the fractions that were rich in phenolic compounds were also the most active in the phytotoxicity assays, suggesting that phenolic compounds have phytotoxic properties. Notable among the phenolic compounds reported to have phytotoxic effects are the derivatives of benzoic and cinnamic acids, the most common being chlorogenic acid, p-coumaric acid, ferulic acid, caffeic acid, p-hydroxybenzoic acid, syringic acid and vanillic acid.

Representatives of the coumarin, quinone, flavonoid and tannin classes are also known to be inhibitors of seed germination and plant growth (Harbone 1997; Malheiros \& Peres 2001). There have also been studies showing that the concentration of phenolic compounds is correlated with the germination and growth of seedlings (Reigosa et al. 1999; Murakami et al. 2009). Polyphenols such as tannins, flavonoids and phenolic acids are the most common compounds with allelopathic effects found in botanical species. Tannins form irreversible complexes with proteins, which can inhibit enzyme processes. Studies have demonstrated that polyphenols interact with biological systems and participate in enzymatic reactions, as well as being antioxidants, suggesting that they are capable of inhibiting the germination and growth of plants (de Bruyne et al. 1999).

Some classes of allelochemicals inhibit plant growth by inducing changes in the chlorophyll content of the target plants (Chou 1999). The chlorotic appearance of the plants evaluated in the present study is likely a symptom of degradation of the chlorophyll molecules or of the inhibition of its synthesis, both of which are mediated by allelochemicals, 


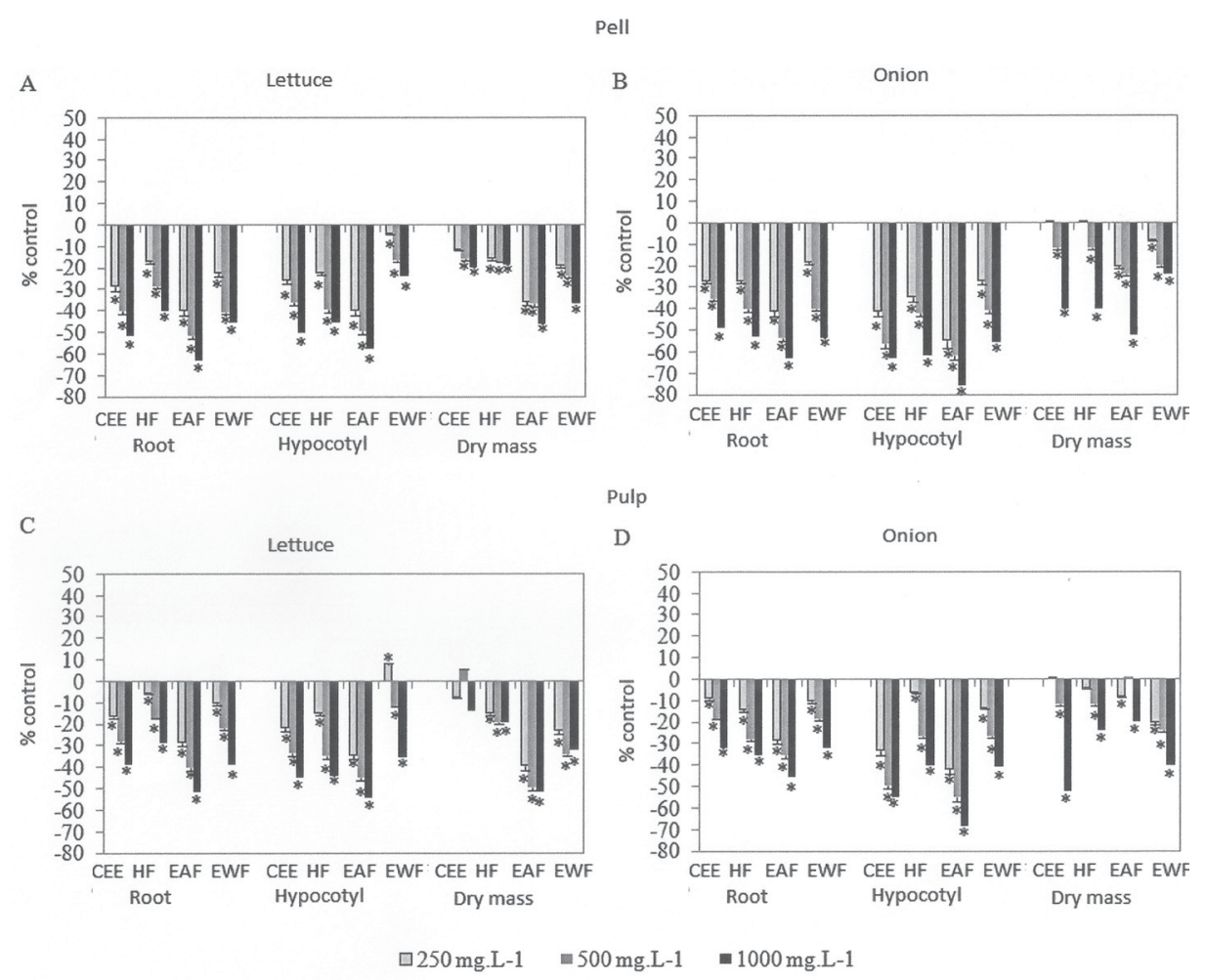

Figure 1. Root length, hypocotyl length and dry mass of Lactuca sativa L. cv. Grand Rapids (lettuce) and Allium cepa L. cv. Baia Periforme (onion) treated with different concentrations of the crude ethanol extract (CEE), hexane fraction (HF), ethyl acetate fraction (EAF) and ethanol-water fraction (EWF) obtained from the peels (A and B) and pulp (C and D) of the fruits of Acrocomia aculeata (Jacq.) Lodd. Ex Mart.
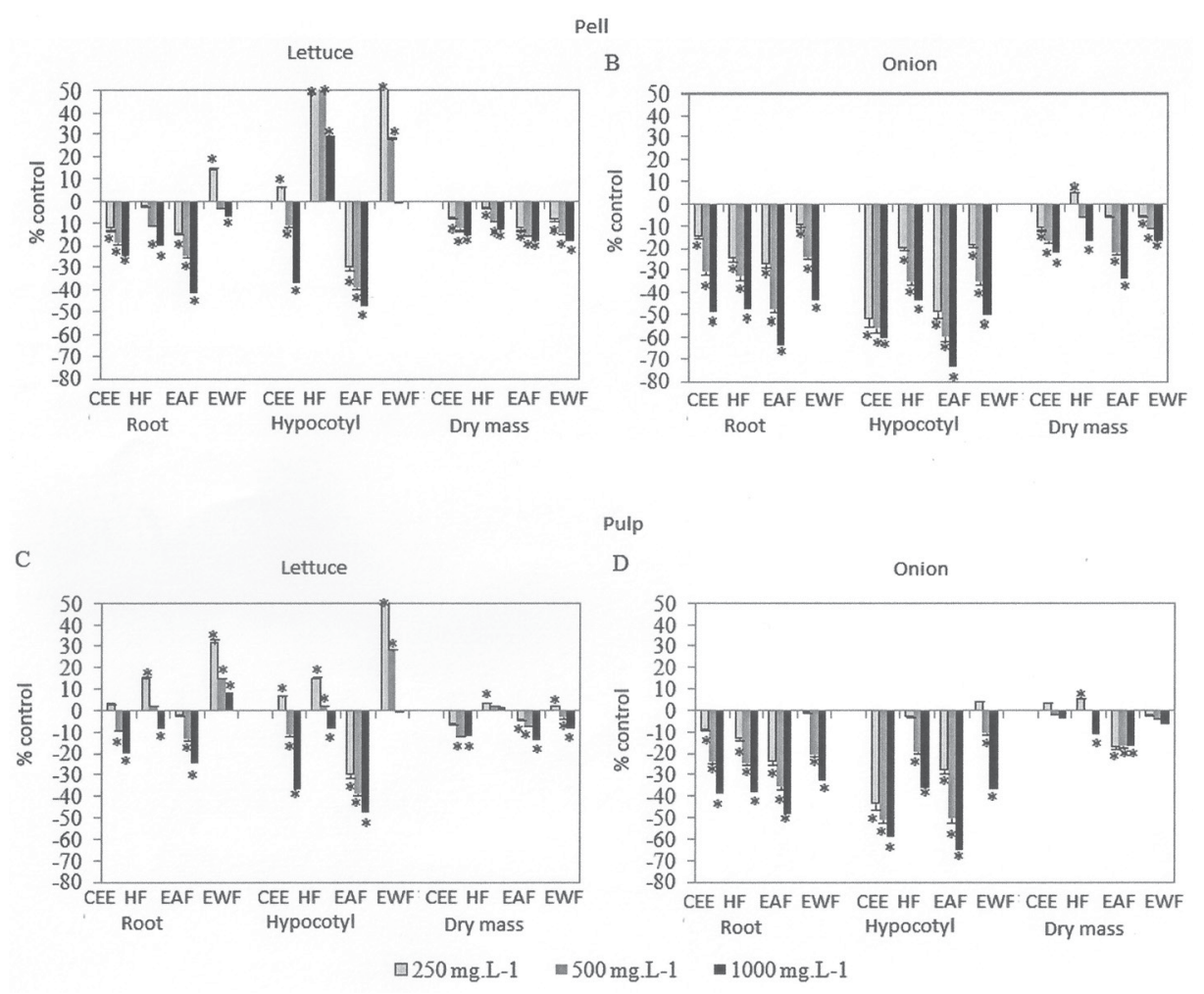

Figure 2. Root length, hypocotyl length and dry mass of Lactuca sativa L. cv. Grand Rapids (lettuce) and Allium cepa L. cv. Baia Periforme (onion) treated with different concentrations of the crude ethanol extract (CEE), hexane fraction (HF), ethyl acetate fraction (EAF) and ethanol-water fraction (EWF) obtained from the peels (A and B) and pulp (C and $\mathrm{D}$ ) of the fruits of Tamarindus indica $\mathrm{L}$. 
Marize Terezinha Lopes Pereira Peres, José Rodrigo Regis Lopes, Cristiane Bezerra da Silva,

A

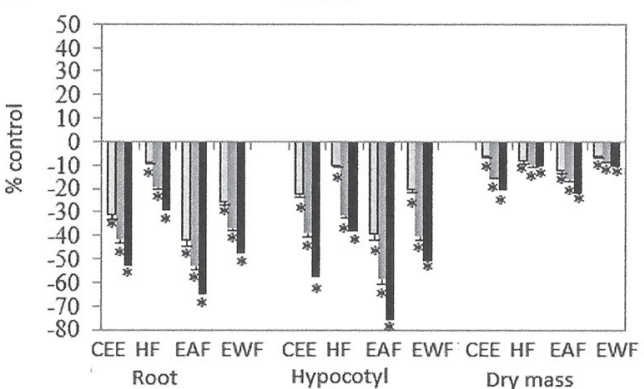

B

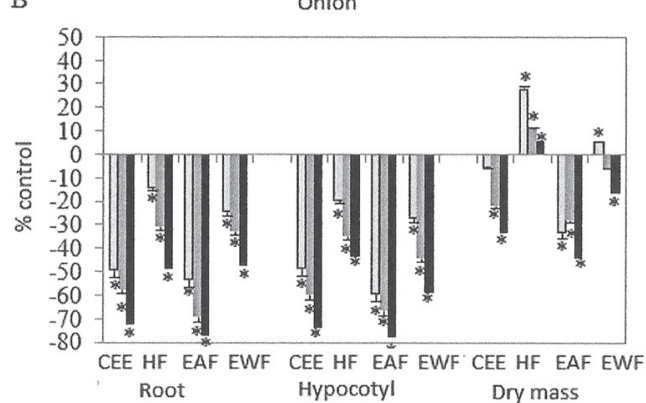

C

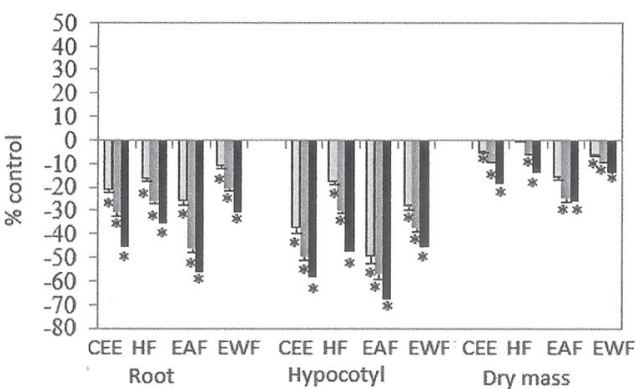

D

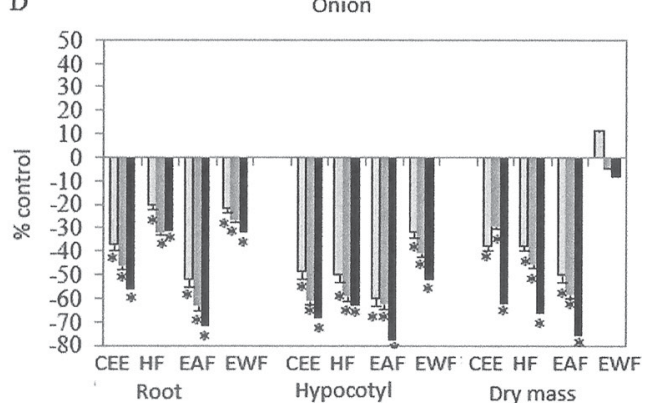

$\mathrm{E}$

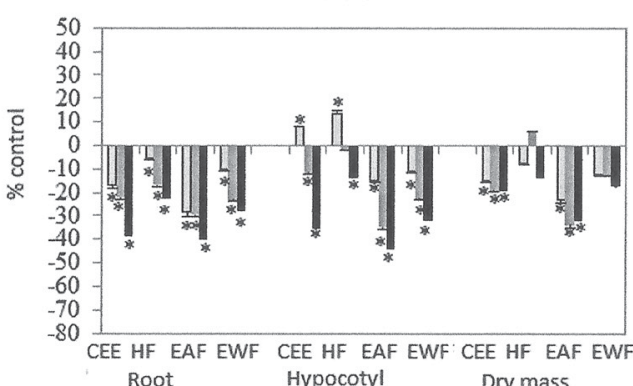

F

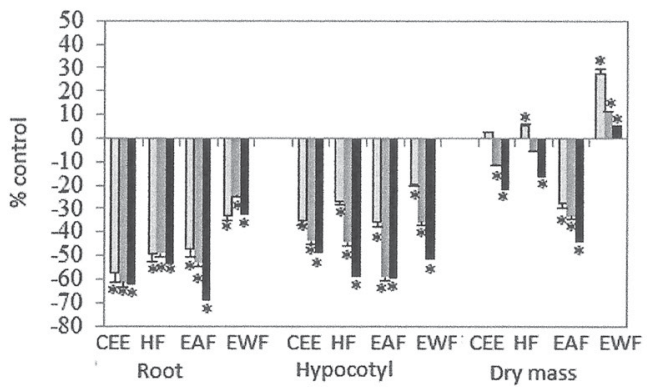

$\square 250 \mathrm{mg} . \mathrm{L}-1=500 \mathrm{mg} . \mathrm{L}-1=1000 \mathrm{mg} . \mathrm{L}-1$

Figure 3. Root length, hypocotyl/coleoptile length and dry mass of Lactuca sativa L. cv. Grand Rapids (lettuce) and Allium cepa L. cv. Baia Periforme (onion) treated with different concentrations of the crude ethanol extract (CEE), hexane fraction (HF), ethyl acetate fraction (EAF) and ethanol-water fraction (EWF) obtained from the whole fruits of Byrsonima intermedia A. Juss. (A and B), Psidium firmum O. Berg (C and D) and Ficus obtusifolia Kunth (E and F).

which impede the formation of magnesium porphyrins (Einhellig 1986). Allelopathic compounds of Dactylis glomerata $\mathrm{L}$. affect the photosynthesis of other plants, exerting an effect similar to that of the herbicides fluometuron and linuron (Reigosa et al. 1999), whereas the phenolic acids, coumarins, polyphenols and flavonoids have been shown to act as herbicides that inhibit photosynthesis, altering electron transport and phosphorylation in photosystems (Durigan \& Almeida 1993).

The allelopathic properties of fruit species in Brazil have yet to be studied in depth. Some studies have evaluated the allelopathic and herbicidal properties of essential oils obtained from species collected in the pantanal (swampland) and cerrado (savanna) of the state of Mato Grosso do Sul. Simionatto et al. (2009) found that essential oils obtained from the bark and leaves of Croton urucurana also showed an herbicidal effect on the germination and growth of lettuce and onion, inhibiting growth by $100 \%$ in comparison with a control. The authors attributed that activity to the presence of borneol and 1-8-cineole. Silva (2009) found that the essential oil of the leaves of Hydrocotyle bonariensis, which is rich in monoterpenes (58.1\%), such as (+)-limonene, exerts allelopathic effects on the germination and growth of lettuce and onion. Some ethanol extracts and semipurified fractions obtained from species of the cerrado also exhibit herbicidal effects (Peres et al. 2009; Candido et al. 2010). 
Among the species cited in the present study, those that presented the greatest antioxidant potential were Acrocomia aculeata (peel), Tamarindus indica (peel), Byrsonima intermedia (whole fruit) and Psidium firmum (whole fruit). We also found that the fruit parts with the highest total phenolic content and the most active in scavenging DPPH free radicals were the peels of the fruits. Among those extracts, the EAFs were the most active as antioxidants. The present study showed that some species of fruits in Brazil can serve as sources of antioxidants. However, for some species, such as Tamarindus indica, Hymenaea stigonocarpa and Myrciaria cauliflora, the highest concentration of phenolic compounds and the lowest $\mathrm{IC}_{50}$ against the DPPH free radical were in the peels of the fruits, which are typically discarded during their preparation or when they are consumed fresh. We propose that, in order to take advantage of the antioxidant potential of these fruits, the application of the peels should be studied, with the objective of developing plant-based products that are rich in phenolic compounds, with high concentrations of flavonoids such as anthocyanins, chalcones, isoflavones and biflavonoids.

The allelopathic assays of the fruits of Brazil evaluated in the present study showed that some of the extracts of those fruits had inhibitory effects on the germination and growth of the target species (lettuce and onion), providing evidence of their herbicidal properties. Our results indicate that Allium cepa (onion) is more sensitive to allelochemicals than is Lactuca sativa (lettuce), in terms of the growth of the root and coleoptile, suggesting that the substances present in the fruits are more active during the post-emergence phase in onions, resulting in phytotoxic effects that are more pronounced. Among all of the extracts and fractions evaluated, the phytotoxic effects of the EAFs were greater than were those of the other treatments. The extracts obtained from the peels of the fruits of Acrocomia aculeata and Tamarindus indica, as well as those obtained from the whole fruits of Byrsonima intermedia, presented phytotoxic effects and high total phenolic contents, which indicates that these extracts can have useful applications as natural herbicides and as antioxidants in food and beverages.

\section{Acknowledgments}

This study received financial support from the Fundação de Apoio ao Desenvolvimento do Ensino, Ciência e Tecnologia do Estado de Mato Grosso do Sul (Fundect-MS, Foundation for the Support of Education, Science and Technology in the state of Mato Grosso do Sul), as well as from the Brazilian Conselho Nacional de Desenvolvimento Científico e Tecnológico (CNPq, National Council for Scientific and Technological Development) and Coordenadoria de Aperfeiçoamento do Pessoal do Ensino Superior (CAPES, Office for the Advancement of Higher Education).

\section{References}

Alothman, M.; Bhat, R. \& Karim, A.A. 2009. Antioxidant capacity and phenolic content of selected tropical fruits from Malaysia, extracted with different solvents. Food Chemistry 115: 785-788.

Barbosa, L.C.A.; Maltha, C.R.A. \& Borges, E.E.L. 2002. Síntese e avaliação da atividade fitotóxica de lactonas derivadas de 2,4-dimetil-8-oxabiciclo [3.2.1]-oct-6-em-3-ona. Química Nova 25: 203-208.

Bennett, R.N.; Shiga, T.M.; Hassimotto, N.M.A.; Rosa, E.A.S.; Lajolo, F.M. \& Cordenunsi, B.R. 2010. Phenolics and Antioxidant Properties of Fruit Pulp and Cell Wall Fractions of Postharvest Banana (Musa acuminata Juss.) Cultivars. Journal of Agricultural and Food Chemistry 58: 7991-8003.

BRASIL. Ministério da Agricultura e Reforma Agrária. 2009. Regras para a Análise de Sementes. Brasília, SNDA/DNDU/CLU.

Candido, A.C.S.; Schmidt, V.; Laura, V.A.; Faccenda, O.; Hess, S.C.; Simionatto, E. \& Peres, M.T.L.P. 2010. Potencial alelopático da parte aérea de Senna occidentalis (L.) Link (Fabaceae, Caesalpinioideae): bioensaios em laboratório. Acta Botanica Brasilica 24: 235-242.

Chon, S.U.; Kim, Y.M.; Lee, J.C. 2003. Herbicidal potential and quantification of causative allelochemicals from several Compositae weeds. Weed Research 43: 444-450.

Chou, C.H. 1999. Roles of allelopathy in plant biodiversity and sustainable agriculture. Critical Reviews in Plant Science 18: 609-636.

da Silva, D.B.; da Silva, J.A.; Junqueira, N.T.V.; de Andrade, L.R.M. 2001. Frutas do Cerrado. Brasília, Embrapa informação Tecnológica.

Dayan, F.E.; Romagni, J.G. \& Duke, S. O. 2000. Investigating the mode of action of natural phytotoxins. Journal of Chemical Ecology 26: 2079-2094.

de Bruyne T.; Pieters, L.; Deelstra, H.; Vlietinck, A. 1999. Condensed vegetable tannins: biodiversity in structure and biological activities. Biochemical Systematics and Ecology 27: 445-449.

Duke, S. O.; Scheffler, B. E. \& Dayan, F. E. 2001. First European Allelopathy Symposium. Vigo, Spain,

Duke, S.O. \& Abbas, H. K. 1996. Natural products with potential use as herbicides. Pp. 348-362. In: Narwal, S.S.; Tauro, P. (Eds.) Allelopathy in pests management for sustainable agriculture. Jodhupur, Scientific Publisher.

Durigan, J.C.; Almeida, F.L.S.. 1993. Noções sobre alelopatia. Jaboticabal, FUNEP.

Duthie, G.G.; Duthie S.J. \& Kyle J.A.M. 2000. Plant polyphenols in cancer and heart disease: implications as nutritional antioxidants. Nutrition Research Reviews 13: 79-106.

Einhellig, F.A. 1986. Mechanisms and modes of action of allelochemicals. Pp. 171-188. In: Putnam, A.R. \& Tang, H.J. (Eds.). The Science of Allelopathy. Nova York, John Wiley and Sons.

Ferreira, A.G. \& Aquila, M.E. 2000. Alelopatia: uma área emergente da ecofisiologia. Revista Brasileira de Fisiologia Vegetal 12 (edição especial): 175-204.

Guo, C.; Yang, J.; Wei, J.; Li, Y.; Xu, J. \& Jiang, Y. 2003. Antioxidant activities of peel, pulp and seed fractions of common fruits as determined by FRAP assay. Nutrition Research 23: 1719-1726.

Gusman, G.S.; Bittencourt, A.H.C. \& Vestena, S. 2008. Alelopatia de Baccharis dracunculifolia DC. sobre a germinação e desenvolvimento de espécies cultivadas. Acta Scientiarum Biological Sciences 30(2): 119-125.

Harbone, J. B. 1997. Recent advances in chemical ecology. Natural Products Report 14: 83-98.

Heim, K.E.; Tagliaferro, A.R. \& Bobilya, D.J. 2002. Flavonoid antioxidants: chemistry, metabolism and structure-activity relationships. The Journal of Nutritional Biochemistry 13: 572-584.

Hervert-Hernández, D.; García, O.P.; Rosado, J.L.; Goñi, I. 2011. The contribution of fruits and vegetables to dietary intake of polyphenols and antioxidant capacity in a Mexican rural diet: Importance of fruit and vegetable variety. Food Research International 44: 1182-1189.

Inderjit, I.; Duke S.O. 2003. Ecophysiological aspects of allelopathy. Planta 217: 529-539.

Katalinic, V.; Milos M.; Modun, D.; Musié I. \& Boban, M. 2004. Antioxidant effectiveness of selected wines in comparison with $(+)$-catechin. Food Chemistry 86: 593-600. 
Koli, R.; Erlund, I.; Jula, A.; Marniemi, J.; Mattila, P. \& Alfthan, G. 2010. Bioavailability of Various Polyphenols from a Diet Containing Moderate Amounts of Berries. Journal of Agricultural and Food Chemistry 58: 3927-3932.

Lim, Y.Y.; Lim, T.T. \& Tee, J.J. 2007. Antioxidant properties of several tropical fruits: A comparative study. Food Chemistry 103: 1003-1008.

Lin, J.Y. \& Tang, C.Y. 2007. Determination of total phenolic and flavonoid contents in selected fruits and vegetables, as well as their stimulatory effects on mouse splenocyte proliferation. Food Chemistry 101: 140-147.

Macias, F.A.; Castellano, D. \& Molinillo, J.M.G. 2000. Search for a standard phytotoxic bioassay for allelochemicals. Selection of standard target species. Journal Agricultural and Food Chemistry 48(6): 2512-2521.

Malheiros, A.; Peres M.T.L.P. 2001. Plantas medicinais sob a ótica da química medicinal moderna; Yunes, R. A.; Calixto, J. B., Eds.; Argos: Chapecó.

Manach, C.; Williamson, G. \& Morand, C. 2005. Bioavailability and bioefficacy of polyphenols in humans. II. Review of 97 bioavailability studies. American Journal of Clinical Nutrition 81: 243S-255S.

Mattila, P.; Hellström, J.; Törrönen, R. 2006. Phenolic Acids in Berries, Fruits, and Beverages. Journal of Agricultural and Food Chemistry 54: 7193-7199.

Meda, A.; Lamien, C.E. \& Beecher, G.R. 2005. Determination of the total phenolic, flavonoid and praline contents in Burkina fasan honey, as well as their radical scavenging activity. Food Chemistry 91: 571-577.

Murakami, C.; Cardoso, F.L.; Mayworm, M.A.S. 2009. Potencial fitotóxico de extratos foliares de Aloe arborescens Miller (Asphodelaceae) produzidos em diferentes épocas do ano. Acta Botanica Brasilica 23: 111-117.

Netzel, M.; Netzel, G.; Tian, Q.; Schwartz, S. \& Konczak, I. 2007. Native Australian fruits - a novel source of antioxidants for food. Innovative Food Science and Emerging Technologies 8: 339-346.
Peres, M.T.L.P.; Simionatto, E.; Hess, S.C.; Bonani, V.F.L.; Candido, A.C.S.; Castelli, C.; Poppi, N.R.; Honda, N.K.; Cardoso, C.A.L. \& Faccenda, O. 2009. Estudos químicos e biológicos de Microgramma vacciniifolia (Langsd. \& Fisch.) Copel (Polypodiaceae). Quimica Nova 32(4): 897-901.

Pott, A. \& Pott, V. J. 1994. Plantas do Pantanal. Embrapa.

Proença, C.; Oliveira, R.S. \& Silva, A.P. 2000. Flores e frutos do cerrado. Brasília, Editora Universidade de Brasília; São Paulo, Imprensa Oficial do Estado.

Reigosa, M.J.; Sánchez-Moreira, A. \& González, L. 1999. Ecophysiological approach in allelopathy. Critical Reviews in Plant Science 18: 577-608.

Sharma, O.P. \& Bhat, T. K. 2009. DPPH antioxidant assay revisited. Food Chemistry 113: 1202-1205.

Silva, C.B.; Simionatto, E.; Hess, S.C.; Peres, M.T.L.P.; Simionatto, E.L.; Junior, A.W.; Poppi, N.R.; Faccenda, O.; Cândido, A.C.S. \& Scalon, S.P.Q. 2009. Composição química e atividade alelopática do óleo volátil de Hydrocotyle bonariensis lam (Araliaceae). Química Nova 32(9): 2373-2376

Simionatto, E.; Bonani, V.F.L.; Peres, M.T.L.P.; Hess, S.C.; Candido, A.C.S.; Diraimo, D.L.; Poppi, N.R.; Matos, M.F.C.; Santos, E.C.S.; Oguma, P.M. \& Carvalho, J.E. 2009. Bioactivity and chemical composition of the essential oils of Croton urucurana Baillon (Euphorbiaceae). Journal of Essential Oil-Bearing Plants 12: 250-261.

Sun A.Y.; Simonyi, A. \& Sun, G.Y. 2002. The "French paradox" and beyond: Neuroprotective effects of polyphenols. Free Radical Biology and Medicine 32: 314-318b.

Sun, J.; Chu, Y.; Wu, X. \& Liu, R. 2002. Antioxidant and antiproliferative activities of common fruits. Journal of Agricultural and Food Chemistry 50: 7449-7454a.

Vokou, D.; Douvli, P.; Blionis, G.J. \& Halley, J.M. 2003. Effects of monoterpenoids, acting alone or in pairs, on seed germination and subsequent seedling growth. Journal of Chemical Ecology 29: 2281-2301. 